PIOTR MOSKAL

Forum Pedagogiczne

9 (2019) 2, cz. 1

Wydział Filozofii

Wpłynęło: 16.09.2018

Katolicki Uniwersytet Lubelski Jana Pawła II

Lublin

Zatwierdzono do druku: 5.02.2019

DOI: $10.21697 / \mathrm{fp} .2019 .2 .03$

ORDIC ID: https://orcid.org/oooo-0oo1-9539-3502

\title{
PROBLEM EDUKACJI RELIGIJNEJ W SPOŁECZEŃSTWIE PLURALISTYCZNYM ${ }^{1}$
}

Streszczenie: W tekście pokazuję, że możliwa jest religijna edukacja w społeczeństwie pluralistycznym, to znaczy zróżnicowanym pod względem religijnym, światopoglądowym, kulturowym i etnicznym, o ile wspólnota religijna i wspólnota obywatelska trafnie rozpoznają swoją naturę i celowość. Charakteryzuję naturę obu społeczności, naturę edukacji, naturę edukacji religijnej oraz omawiam odpowiedzialność obu wspólnot za kształt edukacji. Wskazuję na to, że katolicka edukacja uznaje prawo do wolności religijnej i w tym sensie godzi się na religijny pluralizm, a także szanuje autonomię rzeczywistości ziemskich, a więc m.in. świeckość państwa i wartość różnych nauk. Twierdzę, że z punktu widzenia społeczeństwa pluralistycznego istnienie edukacji katolickiej powinno być akceptowane. Edukacja ta nie sprzeciwia się prawu do istnienia w społeczeństwie różnych dyskursów, a jedynie korzysta z prawa do obecności w życiu publicznym także jej dyskursu.

Słowa kluczowe: edukacja religijna; edukacja katolicka; społeczeństwo pluralistyczne; państwo; religia; Kościół katolicki.

\section{Wspólnota obywatelska a wspólnota religijna}

Czy możliwa jest harmonijna i konstruktywna obecność religijnej edukacji w społeczeństwie pluralistycznym, to znaczy zróżnicowanym pod względem religijnym, światopoglądowym, kulturowym i etnicznym? Wiele zależy od tego, jak państwo, jak wspólnota obywatelska rozumie siebie i politykę, oraz od tego, jak rozumie siebie wspólnota religijna. Konkretni ludzie żyją w obu tych wspólnotach, aby móc lepiej zrealizować swój osobowy rozwój ${ }^{2}$. To ważne: racją bytu

1 W tekście wykorzystuję myśli i sformułowania z moich monografii (Moskal 2009, 2012, 2014).

2 Są jeszcze, jak wiadomo, inne społeczności, przede wszystkim wspólnota najbardziej podstawowa, ściśle związana z ludzką naturą, czyli rodzina, a także inne wspólnoty, zrzeszenia, 
społeczeństwa/społeczności jest dobro wspólne umożliwiające osobowe trwanie i rozwój ludzi tworzących daną społeczność. Ważne jest także rozróżnienie dwóch porządków: doczesnego (ziemskiego) i transcendentnego (nadprzyrodzonego, wiecznego) oraz dwóch społeczności: obywatelskiej i religijnej.

Racją bytu wspólnoty obywatelskiej i prowadzonej przez państwo polityki jest doczesne dobro wspólne, a więc m.in. niepodległość, pokój, ład publiczny, wolność i równość wobec prawa, sprawiedliwość i solidarność, dobre prawo, dobre sądownictwo, sprawna gospodarka, dobry system edukacji, opieki zdrowotnej, zabezpieczeń społecznych, słowem wszystko to, co umożliwia ludziom osobowy rozwój.

Świat religii jest bardzo zróżnicowany. Chociaż różne religie pod pewnymi względami są do siebie podobne, to nie ma czegoś takiego, jak jakaś wspólna istota/ natura realizująca się w tym wszystkim, co zwyczajowo nazywamy religią. $W$ tym też tkwi powód, dla którego nie udało się sformułować takiej definicji religii, która obejmowałaby to wszystko, co zwykliśmy nazywać religią, i pozwoliłaby odróżnić to od innych rzeczy. Dlatego w dalszym ciągu, mówiąc o religii, będę miał przede wszystkim na uwadze religię katolicką ${ }^{3}$ i Kościół Katolicki.

Przedmiotem i celem religii katolickiej jest Bóg i osobowe zjednoczenie człowieka z Bogiem. Ten transcendentny cel życia ludzie realizują nie samotnie, ale we wspólnocie Kościoła. W Kościele istnieje społeczny przekaz wiary, norm moralnych, praktyk modlitewnych, kultycznych i ascetycznych. We wspólnocie wierzących człowiek uczy się miłować Boga i bliźniego. We wspólnocie Kościoła dokonują się spotkania z Bogiem przez lekturę Biblii i znaki sakramentalne.

Wobec nietożsamości celów polityki i religii, społeczności obywatelskiej i wspólnoty religijnej w wypowiedziach Kościoła Katolickiego mówi się o rozdziale między polityką a religią (Jan Paweł II 2003, nr 109), o autonomii rzeczywistości ziemskich w stosunku do religii, o świeckości państwa i polityki. W konstytucji Gaudium et spes II Soboru Watykańskiego czytamy, że: „Wspólnota polityczna i Kościół są, każde na własnym terenie, od siebie niezależne i autonomiczne" (Gaudium et spes, nr 76; cyt. za: Sobór Watykański II 2002, s. 592). W tym samym duchu wypowiedział się w V wieku papież św. Gelazy I. Znane są też słowa Jezusa z Ewangelii

instytucje, partie, dzięki którym ludzie mogą osiągnąć cele przekraczające ich indywidualne możliwości.

3 Chociaż termin „religia katolicka” jest dzisiaj stosunkowo rzadko używany, należy jednak do języka dokumentów Kościoła Katolickiego i teologii katolickiej. Zob. np. Pius IX. Qui pluribus (Denzinger, Schőnmetzer 1976, nr 2777); Pius XII. Humani generis (Denzinger, Schönmetzer 1976, nr 3895); Pelczar 1911. Jestem przeciwny traktowaniu terminów „religia” i „religia chrześcijańska” jako terminów rodzajowego i gatunkowego, a terminu „katolicyzm” jako oznaczającego tylko odmianę chrześcijaństwa. Owszem, chrześcijaństwo jest religią, ale religią jest również katolicyzm. Zdaję sobie sprawę, że to, co piszę o religii katolickiej i edukacji katolickiej w większym lub mniejszym stopniu można odnieść także do innych religii i innych religijnych koncepcji edukacji. 
według św. Mateusza: „Oddajcie więc cezarowi to, co należy do cezara, a Bogu to, co należy do Boga" (Mt 22, 21).

Chociaż w praktyce relacje między władzą świecką a duchowną na przestrzeni wieków nie zawsze układały się harmonijnie, to jednak w świecie katolickiego Zachodu obecna była świadomość odrębności porządków państwowego i kościelnego.

Zagrożenia dla dobrych relacji między państwem a wspólnotą religijną płyną z różnych źródeł. Pomijam tu kwestię osobistych ambicji i postaw przedstawicieli obu społeczności.

Jednym ze źródeł konfliktu jest przyjęte przez społeczność obywatelską i władzę państwową stanowisko, wedle którego doczesne dobro wspólne jest jedynym dobrem wspólnym. Stanowisko to neguje transcendentny wymiar życia ludzkiego. Nie uznaje, że dla obywateli, czy przynajmniej części obywateli, doczesne dobro wspólne ma wartość w odniesieniu do realizacji ostatecznego celu ich życia. W takiej sytuacji religia może być postrzegana jako przeszkoda czy zbędny balast w realizacji celów politycznych.

Innym źródłem jest religijna koncepcja państwa wyznaniowego, ustroju teokratycznego, cywilizacji sakralnej, w której nie uznaje się autonomii porządku doczesnego. Sakralną koncepcję cywilizacji dostrzegamy w wielu historycznych i współczesnych religiach, m.in. w islamie, gdzie nie przyjmuje się rozróżnienia między sferą religijną a cywilną, i który jest typem duchowości politycznej (Renard 1993).

\section{Istota religii katolickiej}

Religia katolicka jest sposobem życia ludzkiego, a nie fragmentem czy dziedziną tego życia. Jest osobowym odniesieniem się człowieka do Boga, rozumianego jako źródło i ostateczny cel życia ludzkiego oraz jako przedmiot wiecznej szczęśliwości. Nie jest wyizolowaną dziedziną życia ludzkiego, lecz sposobem tego życia. Jest życiem wiary, nadziei, a zwłaszcza miłości. Jest sposobem życia angażującym sprawności teoretyczne, moralne i wytwórcze. Katolik przeżywa całe swoje życie $\mathrm{w}$ kategoriach przymierza $\mathrm{z}$ Bogiem i realizacji Bożego powołania. Zmierza do Boga drogą czynów moralnie dobrych - aktów wyłanianych w stosunku do Boga, bliźnich, siebie samego, świata przyrody i kultury.

Jeżeli religia jest sprawą całego życia człowieka, a człowiek ze swej natury jest istotą społeczną, zrozumiałe jest to, że jego życie religijne nie ogranicza się do sfery prywatnej, ale ma także wymiar społeczny, publiczny. Ważne jest jednak rozumienie sposobu obecności religii w życiu publicznym. Jak powiedziałem, nie chodzi o budowanie państwa wyznaniowego, czyli takiego, w którym normy specyficznie religijne stałyby się prawem państwowym, cywilnym. Nie chodzi np. o to, aby Kodeks prawa kanonicznego wszedł w zakres prawa państwowego. 
Sądzę, że jest czymś normalnym, że ludzie przeżywają swoją religię społecznie nie tylko w świątyniach, że czasami wychodzą z domów i świątyń na place i ulice, podobnie jak zajmują place i ulice uczestnicy biegów ulicznych, wyścigów, różnych pochodów i demonstracji. Mówi się, że ulice są dla wszystkich.

Za coś normalnego uznać należy również to, że ludzie religijni promują pewien styl myślenia i określone postawy moralne, że wskazują na naturalne, niezbywalne prawa osoby, rodziny, narodu, że wyrażają sprzeciw wobec naruszania podstawowych ludzkich praw - praw poznawalnych niezależnie od Bożego objawienia. Jak zauważa Roger Trigg (2007), dalekie od neutralności byłoby odseparowanie religii i religijnego myślenia od sfery publicznej. To chyba normalne, że katolicy, wyznawcy innych religii, ateiści i agnostycy chcą, zgodnie ze swymi przekonaniami, uczestniczyć w życiu publicznym.

Katolicy domagają się wolności religijnej dla siebie i uznają prawo do wolności religijnej dla wyznawców innych religii, a także prawo do stosownej wolności dla ateistów i agnostyków. Wolność ta jednak powinna być ograniczana wtedy, gdy staje się wynaturzeniem wolności, gdy narusza naturalne uprawnienia osoby, rodziny, narodu. Nie wszystko wolno w imię wolności religijnej, artystycznej, kulturowej albo w imię wolności badań naukowych. Religia, kultura, nauka, sztuka i technika podlegają ocenie moralnej i ocenie w aspekcie tego, czy nie naruszają czyichś naturalnych uprawnień. Jeśli celem państwa jest dobro wspólne w obszarze ziemskim, horyzontalnym, to celem państwa jest też ochrona naturalnych ludzkich uprawnień, także przed zagrożeniami ze strony religii, kultury, nauki, sztuki i techniki.

Autentyczni, a nie tylko deklaratywni katolicy będą kształtowali życie społeczne w kierunku cywilizacji miłości, a więc m.in. cywilizacji prymatu osoby nad rzeczą, bycia nad posiadaniem, moralności nad techniką, miłosierdzia nad sprawiedliwością czy pracy nad kapitałem.

\section{Edukacja katolicka}

Edukacja, mówiąc bardzo ogólnie, to proces wspomagania osobowego rozwoju człowieka od stanu mniej doskonałego do stanu bardziej doskonałego. Taki lub inny kształt edukacji nie jest filozoficznie, światopoglądowo i aksjologicznie neutralny. Zawsze, bardziej lub mniej wyraźnie, w teorii i praktyce pedagogicznej założony jest określony obraz człowieka - tego, kim jest z natury, i na czym ma polegać jego doskonałość, czy jaki ma być cel procesu edukacyjnego.

Rozstrzygnięcia natury światopoglądowej, ogólnofilozoficznej, antropologicznej, etycznej, aksjologicznej zawarte są m.in. w ustroju szkolnym, w regulacjach określających ramy kwalifikacyjne, efekty lub standardy kształcenia, a także w podstawach programowych. Skoro tak się rzeczy mają, to rodzi się pytanie, jaka powinna być edukacja w społeczeństwie pluralistycznym, zróżnicowanym światopoglądowo i religijnie? Czy państwo ma prawo narzucać wszystkim jeden typ edukacji? Wiemy, że tak się często dzieje. Chodziłem do szkoły w czasie, kiedy państwo praktycznie 
posiadało monopol szkolny (szkoły katolickie były bardzo nieliczne) i kształciło w duchu materializmu dialektycznego i historycznego. Chodziłem do szkoły podstawowej i średniej ze świadomością, że szkoła kłamie, zwłaszcza w zakresie przedmiotów humanistycznych i społecznych.

Optymalne rozwiązanie jest takie, gdy istnieje pluralizm szkolny, i gdy edukację prowadzą wszystkie zdolne i chętne do tego podmioty (państwo również, ale nie tylko państwo). Jeśli państwo zbiera podatki od wszystkich obywateli i decyduje się finansować system oświaty i wychowania, wówczas powinno finansować wszystkie typy szkół, w myśl zasady, że pieniądz idzie za uczniem. Nie znaczy to, że państwo nie ma absolutnie nic do powiedzenia w kwestii edukacji prowadzonej przez różne podmioty - powinno to robić w tym zakresie, w jakim jest zobowiązane do troski o dobro wspólne. Nie powinno np. zezwalać na istnienie jednostek edukacyjnych nastawionych antycywilizacyjnie, kwestionujących naukę, promujących postawy aspołeczne i nienawistne. Państwo nie może być aksjologicznie neutralne.

Edukacja religijna dokonuje się w domu, w miejscach kultu, w stowarzyszeniach i grupach religijnych oraz w szkole -prowadzonej przez wspólnotę religijną lub nie. Jeżeli wspólnota religijna prowadzi szkołę, jej możliwości edukacji religijnej są większe, niż w przypadku, gdy prowadzi lekcje religii nie we własnej szkole ${ }^{4}$.

Jeśli religia jest sposobem życia człowieka, a nie jedynie fragmentem tego życia, odizolowanym od innych dziedzin życia, to szeroko rozumiana edukacja katolicka będzie rozumiana jako integralna formacja osoby -zakładająca katolicką koncepcję człowieka i jego przeznaczenia oraz wizję życia ziemskiego jako realizacji Bożego powołania i zmierzania do osiągnięcia ostatecznego celu życia ludzkiego.

Edukacja religijna to na pewno przekaz tradycji dogmatycznej, moralnej, liturgicznej Kościoła i promocja tejże tradycji. Katecheta to nie tylko nauczyciel, lecz także świadek wiary Kościoła. Co więcej, edukacja religijna to także wysiłek, aby z poszanowaniem godności i wolności ucznia doprowadzić wychowanka do religijnej inicjacji i pogłębienia więzi z Bogiem. Szeroko rozumiana edukacja religijna to także formacja w zakresie kultury duchowej, a więc nauki, moralności, umiejętności artystyczno-technicznych, oraz kultury fizycznej.

Tak rozumiana edukacja religijna (będąca jednocześnie edukacją do religii) z następujących racji nie stoi w opozycji do rzeczywistości społeczeństwa pluralistycznego:

1. Katolicka edukacja przyjmuje do wiadomości fakt światopoglądowego i religijnego pluralizmu. Przekonana o pełni objawienia w Chrystusie i o jedynym

4 Także wtedy, gdy wspólnota religijna ma do dyspozycji jedynie lekcje religii/katechezy, możliwa jest religijna edukacja szanująca religijny pluralizm. Znamienne w tym względzie są wspomnienia Israela Eugenio Zollego (2007, s. 49): „My, chłopcy żydowscy, bardzo lubiliśmy chrześcijańskich kolegów, a oni lubili nas. Nic nie wiedzieliśmy o rasizmie, za to umieliśmy uznawać różne religie i dlatego gdy nadchodziła lekcja religii, każdy trafiał do właściwej klasy. Po skończonej lekcji znowu zbieraliśmy się razem". 
pośrednictwie zbawczym Chrystusa potrafi dostrzec pozytywne elementy w innych religiach. Nie rezygnuje z misji ad gentes i z dawania świadectwa Chrystusowi, ale szanuje wolność człowieka i uznaje, że prawdy nie można nikomu siłą narzucić, że człowiek powinien sam, od wewnątrz, rozpoznać prawdę i związać się z nią.

2. Edukacja katolicka uznaje wartość świeckich nauk i ich autonomię. Katolicyzm jest religią logosu. To prawda, że dochodziło w przeszłości do konfliktów między uczonymi i władzą kościelną, ale generalnie stosunek tejże władzy do nauki i ludzi nauki był na przestrzeni dziejów pozytywny, a naukami świeckimi zajmowało się wielu duchownych (Woods 2006).

Warto jednak zwrócić uwagę na następujące problemy. Po pierwsze, groźna dla człowieka i kultury jest mentalność naukowo-techniczna (mentalność scjentystyczna). Mentalność ta uznaje za wartościowe poznanie właściwe tylko tzw. naukom szczegółowym, zwłaszcza matematycznemu przyrodoznawstwu. Z góry wyklucza poznanie mądrościowe. Nastawiona jest na taki opis świata, który przyporządkowany jest jego instrumentalizacji. Gubi moralny i transcendentny wymiar ludzkiego życia. Równie groźna jest postawa antyracjonalna, polegająca na bezmyślności lub ucieczce w mit, zabobon czy wiedzę tajemną. W pedagogice trzeba dostrzegać pluralizm ludzkiego poznania i ludzkiej wiedzy. Istnieje więc poznanie teoretyczne i afektywne. W poznaniu teoretycznym możemy wyróżnić wiedzę i wiarę. Ze względu na cel poznania wyróżniamy natomiast poznanie teoretyczne, moralne, artystyczne, techniczne. Nauki zaś mogą być teologiczne, filozoficzne, formalne, przyrodnicze, humanistyczne, społeczne. Wszystkie typy poznania, w odpowiednich proporcjach, powinny znajdować się $\mathrm{w}$ programie edukacji, także katolickiej.

Po drugie, nauki szczegółowe, zwłaszcza humanistyczne i społeczne, mają swoją „bazę zewnętrzną”, a więc przyjęte z filozofii czy światopoglądu założenia, których na swoim gruncie nie uzasadniają, a które rzutują na ich rezultaty poznawcze. W tym obszarze może dochodzić do napięć, konfliktów i nadużyć. „Baza zewnętrzna” różnych nauk szczegółowych dotyczy różnych zagadnień, m.in. realności i racjonalności świata, koncepcji człowieka i społeczeństwa czy natury procesu dziejowego.

Po trzecie, niekiedy z wyników nauk szczegółowych wyprowadza się w sposób nieuprawniony wnioski światopoglądowo doniosłe, a dotyczące np. Boga czy ludzkiej duszy. Nauki przyrodnicze, przykładowo, z racji swego przedmiotu, celu i metody (tzw. naturalizm metodologiczny) nie mogą ani potwierdzić, ani zanegować zdań o istnieniu Boga czy ludzkiej duszy.

W procesie edukacyjnym należy uczyć szacunku dla różnych typów nauki, ludzkiego poznania i ludzkiej, racjonalnej aktywności. Jednym z niedowartościowanych typów poznania, także w edukacji katolickiej, jest filozofia (chodzi mi o filozofię typu metafizycznego, filozofię bytu). Skutkuje to tym, że dla wielu katolików istnienie Boga czy duszy jest sprawą wiary lub odczuć, lecz nie wiedzy. Skutkuje to też tym, że wielu katolików nie dostrzega wyłącznie racjonalnych, niezależnych od 
wiary w objawienie Boże, uzasadnień dla norm moralnych. Ma to fatalny wpływ na kształt społecznych dyskusji dotyczących zagadnień moralnych i prawnych.

3. Edukacja katolicka uznaje, że państwo jest rzeczywistością świecką, a nie sakralną, że polityka jest autonomiczna w stosunku do religii, ale nie w stosunku do sfery moralnej. Polityka bowiem ma charakter moralny, nie istnieje poza dobrem i złem. Charakter moralny ma również religia. Podlega ocenie w kategoriach prawdy i dobra. Zarówno religia, jak i polityka, mogą wymagać moralnego oczyszczenia.

Człowiek zmierza do Boga drogą moralnie dobrych czynów, motywowanych miłością względem Niego. Zrozumiałe więc jest, że Kościół prezentuje i promuje określoną naukę moralną, określone wzorce zachowań w przestrzeni zarówno prywatnej, jak i społecznej, że kształtuje ludzkie sumienia. Kościół nie może z tego zrezygnować. Nauka moralna Kościoła jest na miarę człowieka i w znacznej mierze jest poznawczo dostępna za pomocą wyłącznie ludzkich sił poznawczych, to znaczy niezależnie od Bożego objawienia. Nauka Kościoła często jest obroną zwyczajnej ludzkiej normalności.

Zadaniem edukacji katolickiej będzie więc m.in. formowanie sumienia w polityce, jednak z jasną świadomością, że „Kościół ze swojej strony nie posiada zakresu specyficznych kompetencji w odniesieniu do struktur wspólnoty politycznej: «Kościół respektuje słuszna autonomię porządku demokratycznego i nie ma tytułu do opowiadania się za takim albo innym rozwiązaniem instytucjonalnym czy konstytucyjnym» (Jan Paweł II 1991, nr 47). Kościół nie ma nawet upoważnienia do wkraczania w meritum programów politycznych, chyba że mają one związek z religią i moralnością" (Papieska Rada Iustitia et Pax, 2005, nr 424).

Promocja katolickiej nauki moralnej, która w dużej mierze poznawalna jest za pomocą wyłącznie ludzkiego rozumu, jako tzw. prawo naturalne, nie oznacza usiłowania uczynienia z tej nauki, podobnie jak z prawa kanonicznego, prawa państwowego. Katolicka edukacja nie prowadzi w kierunku państwa wyznaniowego. Będzie jednak uwrażliwiać wychowanków na to, aby prawo państwowe gwarantowało ludzkie, naturalne uprawnienia -uznanie ich nie jest uwarunkowane religijną wiarą.

Sądzę, że z punktu widzenia społeczeństwa pluralistycznego istnienie edukacji katolickiej powinno być akceptowane. Edukacja ta nie sprzeciwia się prawu do istnienia w społeczeństwie różnych dyskursów, o ile nie szkodzą one dobru wspólnemu, a jedynie korzysta z prawa do obecności w życiu publicznym także jej dyskursu. 


\title{
Bibliografia
}

Enchiridion symbolorum, definitionum et declarationum de rebus fidei et morum. (1976). Denzinger H., Schönmetzer A. (red.). Barcinone-Friburgi BrisgoviaeRomae: Herder.

Jan Paweł II. (2003). Ecclesia in Europa. Kraków: Wydawnictwo M.

Jan Paweł II. (1991). Centesimus annus. Wrocław: Wydawnictwo Wrocławskiej Księgarni Archidiecezjalnej.

Moskal P. (2009). Religia i prawda, wyd. 2. Lublin: Wydawnictwo KUL.

Moskal P. (2012). Apologia religii katolickiej. Lublin: Wydawnictwo KUL.

Moskal P. (2014). Traktat o religii. Lublin: Wydawnictwo KUL.

Papieska Rada Iustitia et Pax. (2005). Kompendium nauki społecznej Kościoła. Chodyniecki D., Dalach A., Nowak J. (tłum.). Kielce: Wydawnictwo Jedność.

Pelczar J. S. (1911). Obrona religii katolickiej. T. 1: Jak wielkim skarbem jest religia katolicka i dlaczego ta religia ma dzisiaj tylu przeciwników. Przemyśl: Wydawnictwo Diecezjalne Przemyskie.

Pismo Święte Starego i Nowego Testamentu. (2005), wyd. 5. Poznań: Wydawnictwo Pallottinum.

Renard J. (1993). Islamic spirituality. W: Downey M. (red.). The New Dictionary of Catholic Spirituality. Collegeville, Minnesota: A Michael Glazier Book, The Liturgical Press.

Sobór Watykański II. (2002). Konstytucje, dekrety, deklaracje. (tekst polski, nowe tłum.). Poznań: Wydawnictwo Pallottinum.

Trigg R. (2007). Religion in Public Life: Must Faith Be Privatized? Oxford: Oxford University Press.

Woods Th. E. jr. (2006). Jak Kościół katolicki zbudował zachodnia cywilizację. Kucharczyk G. (tłum.). Kraków: Wydawnictwo AA.

Zolli E. (2007). Byłem rabinem Rzymu... Historia wielkiego nawrócenia. Latore A., Węglarz W. (tłum.). Kraków: Wydawnictwo Salwator.

\section{THE PROBLEM OF RELIGIOUS EDUCATION IN PLURALISTIC SOCIETY}

\begin{abstract}
In the article, I show that religious education is possible in a pluralistic society, that is, in a society diversified in terms of religion, worldview, culture and ethnicity, if the religious community and the civic community accurately recognize their nature and purpose. I describe the nature of both communities, as well as the nature of education, religious education and the responsibilities of both communities for the shape of education. I point out that Catholic education recognizes the right to religious freedom and, in that sense, accepts religious pluralism. Catholic education also respects the autonomy of earthly affairs, including, among other things, secularism of the state and the value of
\end{abstract}


different sciences. I believe that from the point of view of a pluralistic society, the existence of Catholic education should be accepted.

Keywords: religious education; Catholic education; pluralistic society; state; religion; Catholic Church.

Piotr Moskal - profesor nauk humanistycznych, kierownik Katedry Filozofii Religii na Wydziale Filozofii Katolickiego Uniwersytetu Lubelskiego Jana Pawła II w Lublinie. Ważniejsze publikacje monograficzne: Problem filozofii dziejów. Próba rozwiązania w świetle filozofii bytu (1993); Spór o racje religii (2000); Religia i prawda (2009²); Apologia religii katolickiej (2012); Apology for the Catholic Religion (2013); Traktat o religii (2014). Adres korespondencyjny: ul. Radziszewskiego 7; 20-039 Lublin. Adres e-mailowy: piotr. moskal@kul.pl. 